\title{
Movie Promotional Strategies in Tamil Film Industry-the Contemporary Access
}

\author{
Mahesh.V.J, Gigi.G.S, P.Uma Rani
}

\begin{abstract}
ABSTRAC-; Movie Industry of India had many ups and downs since 19th century. Some movies succeed with high box office collection records, while some were not. Some movies takes attention with high promotions while some movies not even noticed by the viewers. Movie viewers have variety of choices on types of movie like realistic, imaginary, fiction and commercial movies. Taking all of them to movie theatre need well planned strategies. As we know like every other service, movies also need Marketing. Movie making houses need to understand the marketing strategies need to be framed and reframed in respect to the nature of movies.

The present research, 'Movie promotional strategies in Tamil film industry-the contemporary approach', deals with promotional aspects of the Tamil Film Industry in recent times. The present study reveals that promotional strategies being followed in Tamil movies creating great impact on movie watchers. Awareness on some creative methods of promotions shall be given special attention to spread out their creative effort to the public. More creative method takes more attention from movie watchers. Road show and flash mobs, YouTube viral videos, video games, mobile apps, product placements, reality shows, audio launch, making videos also influence awareness on creative movie promotional strategies for movie watchers. The movie watchers are most aware of product placements under creative movie promotion strategies.
\end{abstract}

Key words: Movie industry, Flash mobs, Social networking, movie trailers, reality shows.

\section{INTRODUCTION}

\section{INDIAN CINEMA}

The history of Indian cinema dated back to 1896; the art of cinema was first demonstrated by the Lumiere brothers by screening six short films to excited audience in Bombay (Mumbai). Followed by the remarkable presentation of Lumiere brothers, an Indian still photographer, Harish chandra Sankaram Bhatavdekar (Save Dada) who was influenced by Lumiere brothers ordered a still camera form England then. He shot his first film 'The Wrestlers' at the hanging gardens in Mumbai (then Bombay). Film 'the wrestlers' was screened in 1899 and this have been considered as the first ever motion picture of Indian film Industry. Dadasaheb Phalke, the father of Indian cinema released the first ever full-length silent film 'Raja Harichandra' in 1913. This was the first ever Indian film

Revised Manuscript Received on September 10, 2019.

Dr. Mahesh.V.J, Asst. Professor, Saveetha School of Management, SIMATS, Chennai, Tamilnadu, India.

(email: vj.mahesh21@gmail.com)

Dr. Gigi.G.S, Asst. Professor, Saveetha School of Management, SIMATS, Chennai, Tamilnadu, India.

(email: gigi.ananya@gmail.com)

Dr. P.Uma Rani,Professor and Head, Department of Management Studies, Saveetha Engineering College, Thandalam, Chennai, Tamilnadu, India.

(email:umapurusothaman@yahoo.co.in) screened in London in 1914 and this movie was made in Marthi language. The number of production companies increased in early 1920s and mythological and historical films from epic Mahabharata and Ramayana were dominated and welcomed by Indian audience. Hollywood had an entry during early 1920s and could highly satisfy audience of Indian movies by offering them action oriented films.

\section{SOUTH INDIAN MOVIE INDUSTRY}

Cinema of South India is combined of five different film industries of South India; Kannada, Malayalam, Tamil, Telugu and Tulu and they are based on Bengaluru, Kochi, Chennai, Hyderabad and Mangalore respectively. Telugu film industry widely known as Tollywood, produces Telugu language movies. This industry became the second largest film industry in India in terms of box office collections, footfalls and number of theatrical release by 2018 .

Kannada film industry produces average of 150 movies per year. This industry colloquially referred as 'Chandanavara' or 'Sandalwood', release their movies more than 1250 screens in Karnataka and across the world. 'Sati Sulochana', the first Kannada talkie presented in theatre in 1943. Malayalam film Industry, one the most important South Indian film industry, dedicated to the production of films in Malayalam language and belong to south Indian state Kerala. Malayalam cinema is known for portrayal of realistic and relevant subjects with least commercial elements has pioneered various technical, creative and thematic production techniques. This industry is the fourth largest industry in India.

\section{KOLLYWOOD MOVIE INDUSTRY}

Tamil movie Industry is film industry of Tamil Nadu which produces movies in Tamil Language, which is colloquially termed as Kollywood, originated in Kodambakkam, a place in Chennai (Madras). Kollywood film industry is the second largest film industry of India and the largest film industry in South India. Tamil cinema could attain its effective presence in Indian film industry being a secondary hub for Bollywood and other important film sector of India. Tamil films able to acquire global presence during the 20th century through distributing film to many theatres of Srilanka, Singapore, Malaysia, Japan, Middle East, Oceania, Europe and North America. M. Edwards 
screened a selection of silent short films at the Victoria Public Hall in madras (now Chennai) in 1897. A western entrepreneur Warwick Major built the first theatre in madras and this was a favourite place for the British community then. The cultural influence was the main factor for theme of Tamil films, rich culture of Cholas were influenced Tamil audiences and film makers, so the film makers are easily able to attract the Tamil crowd and satisfy them.

\section{RESEARCH METHODOLOGY}

Descriptive research method used for this research. Primary data were collected from Tamil movie watchers of Chennai city. Secondary data were taken from research papers, published books and published articles, national and international journals, different websites and movie magazines etc. A well-structured questionnaire had used to collect primary data from respondents. Convenience had been circulated in all the 15 zones of Chennai city. The circulation and after rejecting those flaws the remaining 651 are considered for the research.

\section{RESEARCH GAP}

Indian film industry had experienced many changes over a period of time. Researcher found that many studies had been undertaken on the various aspects of Hollywood and industry. Researcher also noticed different creative promotional activities had been following in Tamil movie industry, but proper study was not initiated on the same area and the researcher found a gap on this. Hence the researcher conducted a study on the contemporary movie promotional strategies of Tamil movies

\section{OBJECTIVES}

- To find the awareness of movie watchers about creative movie promotions

- $\quad$ To find out the most aware creative promotional strategy among the respondents

- To offer some suggestions for the best method of movie promotions

\section{REVIEW OF LITERATURE}

Campaign India (2009) reported, movie marketing has become more systematic and creative. Ubiquitous is how one can describe brand "Ghajini". One can find its presence in all mediums like TV, print, outdoor, internet, mall activation, cinema activation and even in the advertisements of other brands. Movie marketing in India has progressed and is becoming more innovative in approach.

Timothy Cheng (2014) had done a case study method of research with some primary questionnaire on public relations and promotions in film. He reviewed few factors like advertising, public relations, TV talk shows and social media marketing. He concluded that the creative component such as trailer, promotional posters, have good impact in the marketing. sampling method is used by researcher to collect the response with wide range of variance. 800 questionnaires researcher was able to obtain only 672 responses after the Bollywood film Industry and very few studies in Tamil film

Moyra (2012) first flash mob was created in Manhattan in 2003 by Bill Wasik, and the first attempt was failure as he failed to gather people but the second was successful. Since then flash mob has been used as a successful visual marketing technique for brand promotions and awareness. He stated that a well-organized and entertained flash mob has potential to grab attention of audience and go viral.

Grassroots (2015) unlike traditional forms of advertising, flash mobs has been progressed in recent years as the brands uses to surprise their customers. Flash mobs capture the attention of audience and the video became viral where a corporate can use this video as a tool for brand promotion. Flash mobs provide instant recognition and it can boost social media campaigns at low cost.

Sharda \& Bharati (2016), the evolution of new electronic marketing techniques like word-of-mouth publicity, viral marketing communication, has emerged due to advancements in digital communication. Online marketing helps organization to grow further, through company websites, blogs and social networking sites. The study concluded that such viral marketing techniques are powerful factor to influence purchasing behavior of consumers.

Yiannakoulias et al. (2017) conducted a study to check the availability of YouTube videos. The authors found very less content uploaded by government and academic bodies whereas more videos tend to contain celebrity content and personal stories. They also found that YouTube is probably to be snubbed unless it is made more interesting to modern customers.

Hee Jin et al. (2016), conducted a study to understand usage of image search mobile app. The results of this research show that the understanding of generational difference has been improved in accepting new marketing technology. Apps can be used for entertainment, pleasure and customer satisfaction which lead to brand improvements, exposure and promotions. Marketers pay attention to which aspect of mobile app has the positive impact and which has negative impact on consumers, thereby they bring up more creative and innovative methods of promotions though mobile app that takes attention.

Mahesh \& Dr. Umarani (2014) Film stars consuming the sets of reality TV shows either as participants, hosts or judges has become quite common today. Salman Khan had appeared in khaki on Colors channel's 'Laagi Tujhse Lagan' to promote his movie 'Dabangg'. Recently, he had chosen the sets of 'Na Aana Iss Desh Lado' to promote his movie 'Bodyguard'

Sonal \&Vandana (2011) conducted a study with an objective to understand the phenomenon of brand placements in Indian movies. Study found that the most common style of execution is showing the brand and found that brands were highly established in Indian Movies. This type of promotion techniques is far high in Hollywood movies.

Gouri Shah (2014) stated that a consumer products company like HUL is likely to invest about Rs.30 Crore in marketing and promoting their products in Bollywood 
movies. HUL is the largest fast moving consumer goods taken its brand Sunsilk to a Bollywood movie. Film makes and production houses are welcoming the ides of promoting such tie-ups as it would help them to cover production cost with less risk even before the film release.

\section{CONTEMPORARY APPROACH TOWARDS PROMOTIONS}

Marketing in the 21st century seems to be difficult in the present competitive scenario. More communication choices, creative options, more customer choices, involvement of social media, e-word-of-mouth, digitalization and technical advancements are those keep marketing and promotional activities of product and services challenging. The brilliant combination of those challenging factors brings the effective result and benefits to organization. Companies may have to find the best attractive methods of promotion in the most creative form to take attention of their target audience.

Promotion is the communication process of marketing which involves lots of information, inducement and impact. A clear message, which is targeted to a certain group of audience and communicated through well-defined media channel, is considered an effective promotion. The main objectives of successful promotional strategies are to influence, to inform, to understand the customers and finally to build long-lasting relationship with them. Promotional strategies mainly used to attract and create awareness among communicate the benefits of product and services to customers. Every promotional activity will have some expected outcomes and those outcomes decide life of the product and services.

Effective promotional strategy definitely would surprise the business in future. Such benefits are like, increase brand awareness, recognition, high outreach, increase in customer traffic, providing proper information, and help to build sales and profits. In general, every promotional activity fills the gap between firm and customers. Facing a competitive market, firm can attain competitive advantage by ensuring the best service to their customers. It also increases the speed of product acceptance among customers. For the successful implementation of promotional activity, firm shall consider segmentation, targeting, positioning, messaging etc. Different promotional techniques, or activities have been followed by many companies; advertisements of various forms like newspaper, television, radio, public relations, and personal selling etc. bring more movie watchers to theatre. Effective promotional strategies take the business to long-term success.

\section{Contemporary promotional practices in Tamil film industry.}

Marketing is an essential part of movie business and promotions of movies are very vital and challenging like every other product and services. Movie makers come out with a well-defined plan for their movie promotion. In the present scenario, movie promotions start from at the early stage itself. Traditional forms of movie promotions transformed to modern movie promotions with more technological and creative applications. Technological developments stand as a main pillar for movie promotions in the people. Promotion is considered as key element to

21st century. Digital posters, mobile applications, 3-D posters, social media networks, video games, road shows, flash mobs, product tie-ups are some of the most important and creative methods of movie promotions in the present scenario. Role of social media in movie promotion is unavoidable and unforgettable. Most of the promotional activities are well noted by viewers, but still some are not. Here some of the following are the creative and remarkable movie promotions being undertaken by the makers of movies which could grab the attention of movie viewers.

Movie 3 had released their famous song 'Why this kolaveri kolaveri di' in YouTube which became mass hit and created a sensation to viral marketing by receiving 1.3 million viewers in YouTube and more than one million shares on Facebook within the few days of the song release. Autorikshas were used to promote the movie 'Vathikuchi' which revolved a story of an auto driver. Around 100 autos were decorated with movie posters and stationed near major theatres few days before the movie released. MBA students and retain chains were used by movie makers of 'Krishnaveni Panjaalai' for movie promotion with an intention to create word-of-mouth communication as much as possible. Movie which revolved the story of a landlord and his favourite vintage car padmini, 'Pannaiyarum Padminiyum' organized a road show in their padmini car in famous cities like Nagercoil, Coimbatore and Chennai to take attention of movie watchers. Mobile application was created for the promotion of movie 'Mundasupatti' where the users can create their own avatars and style of turban. The app has been designed by mixing various styles of Mundasu (turbans), retro styled eye wears and retro hair styles from the 1980 s.

Song 'Lungi dance' by Yo Yo Honey sing from the movie 'Chennai Express' was great hit in YouTube and had more shares in other social networking sites. The team also launched a unique game; with a theme of the user can fight road side goons to score maximum points in the game; as part of the movie promotion. Movie that dealt with the story of theatre artists in 20th century, 'Kaaviya Thalaivan' tried a very different way of promotion. They organised road show by using theatre artists and performed a small scene from their movie in rural areas as part of their promotion. Team 'Kochadaiiyaan', had used different promotional strategies to attract the movie viewers. 3D posters, Video games, and making videos of movies were highlighted and widely accepted.

'Baahubali' was not an exceptional, which was a visual treat to Indian movie watchers due to the usage of VFX as its technical advancements. Releasing making videos of the movie was the most attracted promotion of this movie and they had released pre-production, designing sets and technical details, efforts of actors were shown in different videos in different time which created curiosity and interest among the movie watchers of all around. Reality shows also been used to promote movies. Actor Vikram presented himself on leading reality show in Hindi Big Boss season 8 for the promotion of his movie 'I'. Kamala Hassan also

Published By: 
presented himself on Big Boss Malayalam season 1 to promote his new movie Viswaroopam II. He visited the Big Boss house and interacted with the contestant and shared information about his new film Viswaroopam II. The splendid audio launch created great buzz for the movie 'I' due to the presence of famous actor 'Arnold Schwarzenegger' from Hollywood. This opened more opportunities of movie promotions through audio launch.

ANALYSIS \& RESULTS

Awareness on road shows and flash mobs

\begin{tabular}{|l|c|c|c|c|c|}
\hline \multicolumn{1}{|c|}{ Variables } & $\mathrm{N}$ & Mean & SD & t value & Sig. \\
\hline Road show as new technique & 651 & 2.1352 & .52346 & -42.154 & .000 \\
\hline Increasing awareness & 651 & 2.6774 & 1.20273 & -6.843 & .000 \\
\hline Flash mobs & 651 & 3.5054 & .92880 & 13.883 & .000 \\
\hline Flash mobs take attention & 651 & 3.4823 & .90515 & 13.596 & .000 \\
\hline Involvement of celebrity & 651 & 3.1429 & .88554 & 4.116 & .000 \\
\hline
\end{tabular}

Table specifies that out of 5 variables, mean value of two variables are less than 3 and mean value of others three variables are more than 3 . Hence it is found that the respondents moderately agree that they are aware of using flash mob as new promotional techniques to promote Kollywood movies, takes immediate attention. It is also found from the table that the respondents highly disagree that they are not aware of using road shows as a movie promotion techniques. This can be inferred as using road shows in Kollywood movie promotion has not been recognised by movie viewers of Kollywood, and the movie goers in Chennai city are not aware of using road show for movie promotion.

Awareness on YouTube viral videos

\begin{tabular}{|l|c|c|r|r|l|}
\hline \multicolumn{1}{|c|}{ Variables } & $\mathrm{N}$ & Mean & \multicolumn{1}{c|}{ SD } & \multicolumn{1}{c|}{ t value } & Sig. \\
\hline Watch trailer & 651 & 4.2135 & .80510 & 38.458 & .000 \\
\hline Viral videos & 651 & 4.0599 & .70891 & 38.147 & .000 \\
\hline Songs of movies & 651 & 3.0860 & 1.19819 & 1.832 & .067 \\
\hline Preference & 651 & 2.8295 & 1.17413 & -3.705 & .000 \\
\hline Viral trailer & 651 & 2.6682 & 1.20660 & -7.016 & .000 \\
\hline
\end{tabular}

Table indicates that out of 5 variables, mean value of two variables are less than 3 and mean value of others three variables are more than 3 . It can be noticed that the respondents strongly agree to watch trailer and viral videos, means that the respondents always prefer to watch trailer of a movie in YouTube and viral videos that create a buzz among the audience. The respondents neither agree nor disagree that they are aware of the movie songs that goes viral and creating buzz in the mind of audience. Also found that the respondents highly disagree that they don't watch a movie just because of the trailer or song that went on viral. This can be inferred as the movie viewers in Chennai are aware of using viral videos as a new technique for Kollywood movie promotion.

Awareness on video games

\begin{tabular}{|l|c|c|c|c|c|}
\hline \multicolumn{1}{|c|}{ Variables } & $\mathrm{N}$ & Mean & SD & t value & Sig. \\
\hline Aware of video games & 651 & 2.7404 & .97754 & -6.776 & .000 \\
\hline Seen video games & 651 & 2.8356 & .93760 & -4.473 & .000 \\
\hline Played video games & 651 & 3.0553 & .93480 & 1.509 & .132 \\
\hline Game lovers & 651 & 2.8664 & .96027 & -3.551 & .000 \\
\hline
\end{tabular}

It is found that out of 4 variables, mean value of three variables are less than 3 and mean value of others variable is more than 3 . Thus it is found that the respondents highly disagree that they are not aware and seen those video games using for movie promotion. They also disagree that video games will not take games lovers to movie theatre to watch the movie. Some of the respondents neither agree nor disagree that they have played video games that remind a movie. This can be inferred as though some of the respondents played video games related to a movie, but they are not aware that this is a part of Kollywood movie promotional strategy.

\section{Awareness on mobile apps}

\begin{tabular}{|l|c|c|c|c|c|}
\hline \multicolumn{1}{|c|}{ Variables } & $\mathrm{N}$ & Mean & SD & t value & Sig. \\
\hline Aware of mobile app & 651 & 2.0092 & .70813 & -35.699 & .000 \\
\hline Association & 651 & 2.5745 & 1.02217 & -10.621 & .000 \\
\hline Recreate scenes & 651 & 2.6820 & .96011 & -8.450 & .000 \\
\hline
\end{tabular}

It is found that out of 3 variables, mean value of others three variables are less than 3 . The respondents highly disagree that they are not aware of movie promotion through mobile apps and its application associated with. Respondents also highly disagree that they have not used mobile app related to movie. This can be inferred as the viewers of Kollywood movie are not aware of using mobile app as the promotional strategies of a movie, and they have not used such type of applications.

Awareness on product placements

\begin{tabular}{|l|c|c|c|c|c|}
\hline \multicolumn{1}{|c|}{ Variables } & $\mathrm{N}$ & Mean & SD & t value & Sig. \\
\hline Awareness & 651 & 3.8034 & .69817 & 29.360 & .000 \\
\hline Recall product & 651 & 3.6544 & .73090 & 22.844 & .000 \\
\hline Recall movie & 651 & 3.6452 & .80864 & 20.357 & .000 \\
\hline Influence positively & 651 & 3.4977 & .86001 & 14.766 & .000 \\
\hline Influence negatively & 651 & 3.4639 & .82639 & 14.323 & .000 \\
\hline Feel to buy & 651 & 3.1628 & .96136 & 4.321 & .000 \\
\hline As part of movie & 651 & 3.3687 & .95878 & 9.811 & .000 \\
\hline
\end{tabular}

This table shows that mean value of all variables are more than 3 . The respondents are moderately agreed that they are aware of using product placements as part of its promotional strategies. They moderately agree that they are able to recall the product when they see a movie and vice versa. The respondents also moderately agree that positive presentation of product influences positively and negative presentation of a product influences them negatively. They are ready to buy the same product after watching the movie that make them feel as if they are part of that movie.

\section{Awareness on reality shows}

\begin{tabular}{|l|c|c|c|c|c|}
\hline \multicolumn{1}{|c|}{ Variables } & $\mathrm{N}$ & Mean & SD & t value & Sig. \\
\hline Regularly watch & 651 & 3.4700 & 1.11643 & 10.742 & .000 \\
\hline Awareness & 651 & 3.2888 & .93291 & 7.898 & .000 \\
\hline Celebrities share information & 651 & 2.9478 & 1.07576 & -1.239 & .000 \\
\hline Interested and inspiring & 651 & 2.8771 & 1.00167 & -3.130 & .000 \\
\hline
\end{tabular}

The above table indicates that out of 4 variables, mean value of two variables are less than 3 and mean value of other two variables are more than 3 . It is found that the respondents of this research moderately agree that they regularly watch reality shows and aware that reality shows being used to promote the movie. At the same time the respondents highly disagree that celebrity involved in reality show doesn't share all information that the respondents 
needed. This can be inferred as the Kollywood movie watchers in Chennai are not happy with the information provided by celebrity during reality shows about their new release.

Awareness on audio launch

\begin{tabular}{|l|c|c|c|c|c|}
\hline \multicolumn{1}{|c|}{ Variables } & $\mathrm{N}$ & Mean & SD & t value & Sig. \\
\hline Awareness & 651 & 3.6068 & .73310 & 21.118 & .000 \\
\hline Go for audio launch & 651 & 2.6743 & 1.03401 & -8.036 & .000 \\
\hline Contest and game shows & 651 & 1.9969 & .91986 & -27.823 & .000 \\
\hline Create excitements & 651 & 2.4240 & .71143 & -20.659 & .000 \\
\hline Presence of celebrity & 651 & 2.3579 & .59692 & -27.445 & .000 \\
\hline
\end{tabular}

The table indicates that out of 4 variables, mean value of two variables are less than 3 and mean value of 1 variable is more than 3 . It is found that respondents moderately aware that audio launch is part of movie promotional strategies. The respondents highly disagree that they would not go for audio launch if they knew about it, participate in contest, creating excitements and presents of celebrity in the audio launch event. This means that the respondent of this research are not interested to participate in movie audio launch event as it is not creating any excitement among the public. They also feel that the presence of celebrity during audio launch will not make much influence on the viewers to watch that particular movie.

\section{Awareness on making videos}

\begin{tabular}{|l|c|c|c|c|c|}
\hline \multicolumn{1}{|c|}{ Variables } & $\mathrm{N}$ & Mean & SD & t value & Sig. \\
\hline Awareness & 651 & 2.3840 & .88751 & -17.708 & .000 \\
\hline Regularly watch making videos & 651 & 2.4086 & .79354 & -19.015 & .000 \\
\hline Creating curiosity & 651 & 2.2919 & .73437 & -24.603 & .000 \\
\hline
\end{tabular}

The above table shows that out of 3 variables; mean value of all three variables is less than 3. It is found that respondents highly disagree that they are not awareness of making video is part of promotion, creating curiosity and watching making video. This means that the respondents of this research are not aware of using making video as part of its promotional strategies. They also feel that they don't have the habit of watching making videos before and after watching the movie. The respondents feel that making videos of those movies are not creating any curiosity among them.

The most aware creative promotional strategy among movie watchers

T-test is used by the researcher to find the most aware creative promotional strategies. The researcher developed 8 different creative promotional activities that are used in movies or movie promotions. Here the researcher testing the awareness of movie watchers on the creative movie promotion of movie makers. In this research the researcher various studies have done by the researcher with different statistical tools to find awareness of movie watchers on the creative movie promotions. Hence the researcher also decided to find the most aware creative promotional activity among the movie watchers and the following table represent the data.
The most aware creative promotional strategy among movie watchers

\begin{tabular}{|c|c|c|r|r|r|c|}
\hline \multicolumn{7}{|c|}{ One-Sample Statistics } \\
\hline Factors & $\mathrm{N}$ & Mean & $\begin{array}{c}\text { Std. } \\
\text { Deviation }\end{array}$ & $\begin{array}{c}\text { Std. Error } \\
\text { Mean }\end{array}$ & t-value & Rank \\
\hline Road shows and flash mob & 651 & 2.6390 & .53157 & 651 & -17.327 & 6 \\
\hline YouTube viral videos & 651 & 3.4409 & .74107 & 651 & 15.179 & 2 \\
\hline Video Game & 651 & 2.8034 & .72731 & 651 & -6.898 & 5 \\
\hline Mobile apps & 651 & 2.3456 & .60413 & 651 & -27.637 & 7 \\
\hline Product Placements & 651 & 3.5860 & .66180 & 651 & 22.593 & 1 \\
\hline Reality Shows & 651 & 3.1736 & .93881 & 651 & 4.717 & 3 \\
\hline Audio launch & 651 & 2.9823 & .46085 & 651 & -.978 & 4 \\
\hline Making Videos & 651 & 2.3379 & .72340 & 651 & -23.351 & 8 \\
\hline
\end{tabular}

It is found that mean varies from 2.3456 to 3.5860 , and the variance from -27.637 to 22.593 . Here product placement scores rank 1 with high mean 3.5860, followed by YouTube viral videos holds 2nd rank with mean 3.4409, and reality shows takes 3rd rank with mean 3.1736. This indicates that the movie watchers are more aware of product placements, YouTube viral videos and reality shows are the most creative movie promotional strategies.

\section{Findings}

The respondents moderately agree that they are aware of using flash mob as new promotional techniques whereas not aware of using road shows as movie promotion method.

The movie watchers strongly prefer to watch movie trailers YouTube. It is also found that the respondents neither agree nor disagree that the movie songs that goes viral creating buzz in the mind of audience.

The respondents highly disagree that they are not aware and never seen video games using for movie promotion; some of the respondents neither agree nor disagree that they have played video games that remind a movie.

Respondents highly disagree that they are not aware of movie promotion through mobile apps, application associated with and they have used mobile app related to movie.

The movie viewers moderately agree that they are aware of using product placements as part of its promotional strategies.

Respondents of this research moderately agree that they regularly watch reality shows and aware that reality shows being used to promote the movie. The respondents highly disagree that celebrity involved in reality show are not giving all information that the respondents need and creating interest.

The respondents moderately aware that audio launch is part of movie promotional strategies. It is also found that the respondents highly disagree that they would not go for audio launch if they knew about it, participate in contest, creating excitements and presents of celebrity in the audio launch event.

The respondents highly disagree that they are not aware of making video is part of promotion, creating curiosity and regularly watching making videos

\section{Suggestions}

More awareness shall be given on movie promotions through road shows. 
Awareness on movie promotions through mobile video games shall be given as most of the respondents were not able to recall or remember the video games related to movies.

Movie promotion through mobile apps needs special attention and coverage among the public.

Presence of celebrity in reality shows are much appreciated by viewers but their involvement shall be more to give more details about the movie which will keep the audience excited.

As the respondents moderately aware that audio launch is part of movie promotional strategies more awareness shall be given. Easy accessibility on audio launch for public shall create positive impact on the upcoming movie.

Making video shall be more focused, to show the difficult situations encountered by the team, funny and happy moments, technological excellence and advancements etc. to create a kind of attention, curiosity, awareness, interest among the target audience.

Some category of movie viewers like students, working professionals, housewives etc. shall be considered for movie promotions.

Promotional activity through self-help group would be a small contribution to women empowerment there by the society will be benefited.

\section{CONCLUSION}

The present study deals with different promotional factors that existing now and created awareness on movie watchers. Movie promotions are moved on from bare bone advertisements to interactive methods which ensure twoway communications with movie goers. An absence or mismatching promotional activity would keep the audience out of theatre, hence the movie promoters and makers have to clearly decide on the method of promotions and medium to reach message to target audience. It requires compete coordination of human resources with technology, equipment, procedures and time, though methods are different for different movies but the goal is one and the same. This study conclude that road show and flash mobs, YouTube viral videos, video games, mobile apps, product placements, reality shows, audio launch, making videos also influence awareness on creative movie promotional strategies for movie watchers. Out of the major promotional strategies considered for this study, movie watchers are most aware on the creative aspects of product placements, YouTube viral videos, and reality shows.

\section{REFERENCES}

1. Andrews J, Smith Daniel C (1996). Factors affecting the creativity of Marketing Programs for Mature Products. Journal of Marketing research, Vol:33 (2).

2. Bahubali 2 Becomes Highest Grosser of All Time in Five Days - Box Office India

3. Gouri Shah (2014). HUL takes the Bollywood route for product launch. Live Mint, E-paper, 2014,

4. Hee Jin Hur, Ha Kyung Lee, Ho Jung Choo (2016). Comparison between millennial and mature consumers. Computers in human behaviour. Vol:73, pp.353-361.
5. Indo-Asian news Service. Mundasupatti makers use innovative promotional strategy The Indian Express, June 2014.

6. Mahesh \& Dr. P.Umarani (2014). Review on movie promotions and creative marketing in a National conference on Research Aspects in Management Prospects \& Entrepreneurship Development Perspectives. (ISBN: 978-93-84743-16-1).

7. Perianayagam Jesudoss, Tamil Cinema, published by Communication Research Trends, Vol: 28 no. 4 pp.1-44, ISSN01444646.

8. Philip Kotler \& Kevin Lane Keller, Marketing Management, 12th Edition, Pearson Education.

9. Sharda Haryani, Bharti Motwani (2016) Discriminant model for online viral marketing influencing consumers' behavioral intention. Pacific science review B:Humanities and social sciences, vol:1, pp.49-56.

10. Sonal Kureshi, Vandana Sood (2011). In-film placement trends: a comparative study of Bollywood and Hollywood. Journal of Indian Business Research, Vol:3 (4), pp. 244-262.

\section{Websites \& URL}

1. www.campaignindia.in

2. http://magnifydigital.com/using-a-flash-mob-to-createbrand-awareness

3. http://www.grassrootsadvertising.com/blog/flash-mob/alook-at-the-benefits-of-flash-mob- marketing/

4. https://nofilmschool.com/2016/02/6-elements-great-film.

5. www.digitalvidya.com/blog/11-social-media-marketingideas-used-by-baahubali-movie-franchise/

6. www.after.marketing/insights/2017/6/1/top-5-benefitsof-promotional-marketing.

7. www.inpeaks.com/2017/10/05/top-10-movie-industriesworld.

8. Surface.syr.edu/honors capstone. 